\title{
Potential water-related environmental risks of hydraulic fracturing employed in exploration and exploitation of unconventional natural gas reservoirs in Germany
}

\author{
Axel Bergmann ${ }^{1 *}$, Frank-Andreas Weber $^{1}, \mathrm{H}$ Georg Meiners ${ }^{2}$ and Frank Müller ${ }^{2}$
}

\begin{abstract}
Background: The application of hydraulic fracturing during exploration and exploitation of unconventional natural gas reservoirs is currently under intense public discussion. On behalf of the German Federal Environment Agency we have investigated the potential water-related environmental risks for human health and the environment that could be caused by employing hydraulic fracturing in unconventional gas reservoirs in Germany. Here we provide an overview of the present situation and the state of the debate in Germany and summarize main results of the conducted risk assessment.
\end{abstract}

Results: We propose a concept for a risk assessment considering the site-specific analysis of the geosystem, the relevance of possible impact pathways and the hazard potential of the fracking fluids employed. The foundation of a sound risk analysis is a description of the current system, the relevant impact pathways and their interactions. An evaluation of fracking fluids used in Germany shows that several additives were employed even in newer fluids that exhibit critical properties or for which an assessment of their behaviour and effects in the environment is not possible or limited due to lack of current knowledge. The authors propose an assessment method that allows for the estimation of the hazard potential of specific fracking fluids, formation water, and the flowback based on legal thresholds and guidance values as well as on human- and eco-toxicologically predicted no-effect concentrations. The assessment of a previously employed and a prospectively planed fracking fluids shows that these fluids exhibit a high hazard potential. The flowback containing fracking fluid, formation water, and possibly reaction products can also exhibit serious hazard potentials, requiring environmentally acceptable techniques for its treatment and disposal.

Conclusions: The risk analysis must be conducted always site-specifically and consider regional groundwater flow conditions. The study concludes that currently missing knowledge and data prevent a profound assessment of the risks and their technical controllability in Germany. Missing knowledge and information includes data on the properties of the deep geosystem and of the behaviour and effects of the deployed chemical additives. In this setting the authors propose several recommendations for further action and procedures regarding the application of hydraulic fracturing in unconventional gas reservoirs in Germany.

Keywords: Hydraulic fracturing; Fracking; Unconventional natural gas; Shale gas; Coalbed methane; CBM; Impact pathways; Chemical additives; Flowback; Hazard potential; Risk analysis

\footnotetext{
* Correspondence: a.bergmann@iww-online.de

'IWW Water Centre, Department Water Resources Management,

Moritzstrasse 26, Muelheim 45476, Germany

Full list of author information is available at the end of the article
} 


\section{Background}

The application of hydraulic fracturing ("fracking") in the exploration and exploitation of unconventional natural gas reservoirs has been generating intensive public debates in a variety of countries. Major concerns have focused on the potential impacts, hydraulic fracturing may cause on the environment and on human health, especially if fracking fluids contain toxic and environmentally harmful chemical additives.

Unconventional gas reservoirs are proven or presumed to be present in a number of different geological formations. An overview of potential geological host formations of unconventional gas reservoirs in Germany is given in Table 1, differentiating coalbed methane (CBM), shale gas and tight gas reservoirs. According to current estimates [1], the technologically recoverable gas reserves present in shale gas reservoirs in Germany amount to about 1,300 billion $\mathrm{m}^{3}$ (estimates range from 0.7 to $2.3 \cdot 10^{12} \mathrm{~m}^{3}$ ), assuming that $10 \%$ of the gas in place (GIP) is technologically recoverable. This estimated range of technologically recoverable shale gas reservoirs could, if exploited completely, cover the current annual gas consumption of Germany for 8 to 27 years [2]. The GIP in coalbed methane reservoirs in Germany is estimated to 450 billion $\mathrm{m}^{3}$ [3], but the technologically recoverable fraction has not yet been analysed. Conventional gas and tight gas reservoirs have been exploited in Germany over several decades, but current estimates of GIP remaining (100 billion $\mathrm{m}^{3}$ and 20 billion $\mathrm{m}^{3}$, respectively [3]) indicate that the remaining reserves are limited.

The mining authorizations that have been issued for the exploration of unconventional gas reservoirs in Germany are shown in Figure 1. Most exploration has yet focused on the recovery and analysis of drilling core material as well as on geophysical methods, but hydraulic fracturing has already been applied in exploration at two sites [4]: at the site Damme 3 in Lower Saxony (3 fracs in the Wealden clay formation in depth of 1,045 - 1,530 m below ground surface using a slickwater fracking fluid in 2008) and at the site Natarp in North Rhine-Westphalia ( 2 fracs in CBM reservoirs in depth of 1,800 - 1,947 m using a gel fluid in 1995). To our knowledge, no mining authorizations have yet been approved for productionoriented exploitation of shale gas or CBM reservoirs in Germany. In the ongoing exploitation of tight gas and conventional gas reservoirs, however, experience in using hydraulic fracturing has been gained by pumping over 300 fracs over the last decades, mainly in the federal state of Lower Saxony [4]. In general, the exploited tight gas reservoirs in Germany are located in greater depth (often $>3.500 \mathrm{~m}$ ) than some of the shale gas and CBM reservoirs currently considered for exploration, which vary in depth but are located partly in depth of $1.000 \mathrm{~m}$ or less [2,4-6], raising additional

Table 1 Potential unconventional gas reservoirs in Germany

\begin{tabular}{lll}
\hline Type of reservoir & Most promising reservoir & Regions \\
\hline Coal bed methane (source rocks) & Seam-bearing Upper Carboniferous & Northern Ruhr region/Münsterland Basin (NRW) \\
lbbenbühen (NRW) & Saar Basin (Saarland) \\
Shale gas (source rocks) & Molasse Basin (BW) \\
& Tertiary clay formations (e.g. Fischschiefer) & Northwest German Basin (e.g. Lünne) (NI) \\
& Posidonia Shale (Black Jurassic)* & Molasse Basin (BW) \\
& & Upper Rhine Graben \\
& Wealden clay formations (e.g. Lower Cretaceous)* & Weser Depression (NRW/NI) \\
& Permian clay formations (e.g. black shale (stinkschiefe"), & Northeast German Basin (NI/SA) \\
& copper shale) & Northern edge of the Rhenish massif (NRW) \\
& Carboniferous and Devonian clay formations e.g. alum shale & Northwest German Basin \\
& (Lower Carboniferous)* & Harz Mountain (NI/SA) \\
& Northeast German Basin \\
& (not yet studied in details) \\
& Cambro Ordovician clay formations ("alum shale") & Northwest German basin (NI/SA) \\
& Red sandstone & Northeast German basin (e.g. Leer) (NI) \\
& Permian sandstones (Rotliegend) and carbonates (Zechstein) \\
Tight gas (deposit rocks) & Permian sandstones (Rotliegend) and dolomite (Stassfurt series) & Thuringian Basin (TH) \\
& sandstones (Triassic) & Northwest German Basin (e.g. Vechta) (NI) \\
\hline
\end{tabular}

*indicates most relevant shale gas reservoirs according to [1]. 


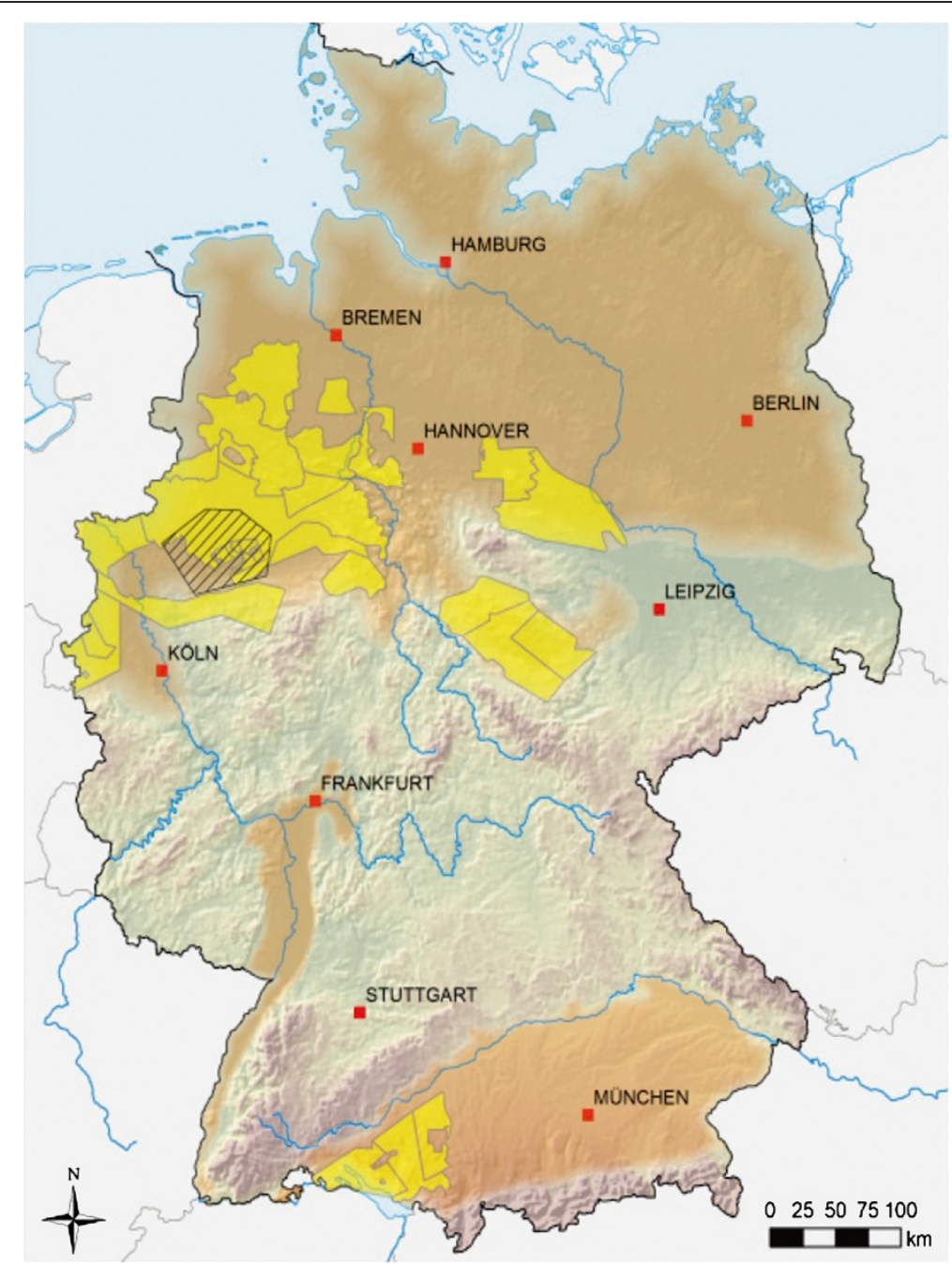

Figure 1 Mining authorizations in Germany (yellow, last revision: 31 December 2011) for exploration for unconventional hydrocarbon reservoirs (ochre: regions with the basic geological conditions for formation of shale gas) [1].

concerns on potential impacts on near-surface groundwater resources.

Driven by reports on the application and risk assessment of hydraulic fracturing in the U.S. [7-11], several risk assessments have recently been conducted on the specific German geological, technical, and legal situation, including an investigation on behalf of the German Federal Environment Agency (UBA) [4], a survey on behalf of the Ministry for Climate Protection, Environment, Agriculture, Nature Conservation and Consumer Protection (MKULNV) of the federal state of North RhineWestphalia [5], and an investigation of an independent expert group initiated by ExxonMobil Production Germany $\mathrm{GmbH}$ [12]. Given the current state of exploration of shale gas and CBM reservoirs in Germany, most risk assessments were conducted generically (i.e. not sitespecific) or focused on some selected geological settings.
Two site-specific investigations on regional situations in northern Hessian and in the river Ruhr watershed have recently been conducted $[6,13]$.

\section{Current state of the debate in Germany}

The political debate on hydraulic fracturing in Germany has proceeded as a result of the conducted risk assessments (or independent thereof), and new administrative procedures have been adapted recently.

The State Authority for Mining, Energy and Geology (LBEG) of Lower Saxony has issued minimum requirements for operating plans, criteria, and approval procedure for hydraulic treatments of boreholes in petroleum and natural gas reservoirs [14]. ExxonMobil Production Germany GmbH, a major operator in Germany, has announced that fracking projects in the vicinity of certain mineral spa protection zones are not further pursuit and 
no further hydraulic fracturing activities are carried out before suitable concepts for groundwater monitoring are implemented [15].

The state of North Rhine-Westphalia is currently not approving any exploration or production of natural gas from unconventional gas reservoirs, if harmful substances are employed [16]. A dialogue process is planned to involve the gas industry and communities, citizens, and relevant institutions in developing criteria for project approval and eliminating deficits of information and knowledge. In this context, borehole investigations, excluding hydraulic fracturing, are discussed for research purposes [17].

According to current press communications [18], the state of Lower Saxony is not approving further exploration and exploitation of shale gas and CBM reservoirs based on the lack of adequate risk assessment, but plans to continue approving exploitation of tight gas reservoirs in sandstone formation in depths $>2.500 \mathrm{~m}$, as long as no environmentally toxic substances are injected underground.

Draft legislations amending the environmental impact assessment (EIA) regulation and of the Water Management Act (WHG) are currently discussed in Germany [19]. The drafts call for a ban of deep drillings involving hydraulic fracturing and the underground disposal of flowback in water protection zones, mineral spa protection zones, and in catchment areas of natural lakes from which raw water is procured directly for the public water supply. Based on the discussed draft legislation, the catchment area of artificial lakes and dams from which water is indirectly obtained for drinking water purposes would not generally be considered an exclusion zone [20].

Two regional investigations have analysed the regional occurrence of shale gas reservoirs in comparison to competing land-use obligations $[6,13]$. In a study on behalf of the river Ruhr water works consortium (Arbeitsgemeinschaft der Wasserwerke an der Ruhr e.V.) and the Ruhr River water board (Ruhrverband), we concluded that considering the regional occurrence of the shale gas reservoirs, the exclusion areas proposed by the draft legislations, and adopting criteria for the approval of exploitation involving hydraulic fracturing issued in Lower Saxony, an area of less than 3\% of the issued mining authorization is accessible for exploitation of the shale gas reservoirs. Furthermore, a legal expertise commissioned by the Hessian Ministry of Environment, Energy, Agriculture and Consumer Protection (HLUG) has noted [13] that mining authorizations must not be granted if competing obligations among public stakeholders preclude subsequent exploitation of the gas reservoirs in the entire allocated field.

In the so-called "Hannover-Erklärung", the Federal Institute for Geosciences and Natural Resources (BGR), the Helmholtz Centre Potsdam - GFZ German Research Centre for Geosciences and the Helmholtz Centre for
Environmental Research (UFZ) have called for the development of environmentally friendly fracking technology and proposed joint demonstration projects involving industry, research institutions, environmental organizations, and the general public [21]. An alliance of water suppliers, the Ruhr River water works consortium, and members of the beverage industry have called for clear legal provisions to protect the safety and purity of water resources from impacts of hydraulic fracturing in the socalled "Gelsenkirchener Erklärung" [22].

Furthermore, the exploitation of shale gas reservoirs is currently discussed controversial from an energy policy point of view. While the Federal Institute for Geosciences and Natural Resources (BGR) concluded that shale gas can contribute to domestic energy security [1], the German Advisory Council on the Environment (SRU) comes to the conclusion that the exploitation of shale gas using hydraulic fracturing is not necessary in Germany from an energy policy point of view and cannot substantially contribute to the transition to renewable energy sources [2].

\section{Objectives}

On behalf of the German Federal Environment Agency (UBA), a consortium of IWW Water Centre, ahu AG, [Gaßner, Groth, Siederer \& Coll.], and Technical University of Darmstadt, has conducted a comprehensive investigation on potential environmental impacts of hydraulic fracturing related to exploration and exploitation of unconventional natural gas reservoirs, which focused on the framework of a risk assessment, the analysis of potential impact pathways, a method for assessing the hazard potentials of the fracking fluids employed, and on legal regulations and administrative structures [4]. Here we summarize main results of this study and propose recommendations for action and procedures. The study is based mostly on publicly accessible information including the relevant literature available internationally, but also on information provided by German authorities and operating companies.

\section{Results and discussion}

For assessing the risks that the application of hydraulic fracturing in unconventional natural gas reservoirs can pose on the water environment, we propose a concept that considers both the possible impact pathways and the potential hazard, any migration of the substances employed or encountered along these impact pathways could cause on exploitable water resources (Figure 2). Only if impact pathways are relevant for substance migration on the time scale considered, the substancerelated hazard potentials cause adverse effects on the exploitable water environment. The risk of contamination of exploitable water resources is thus obtained 

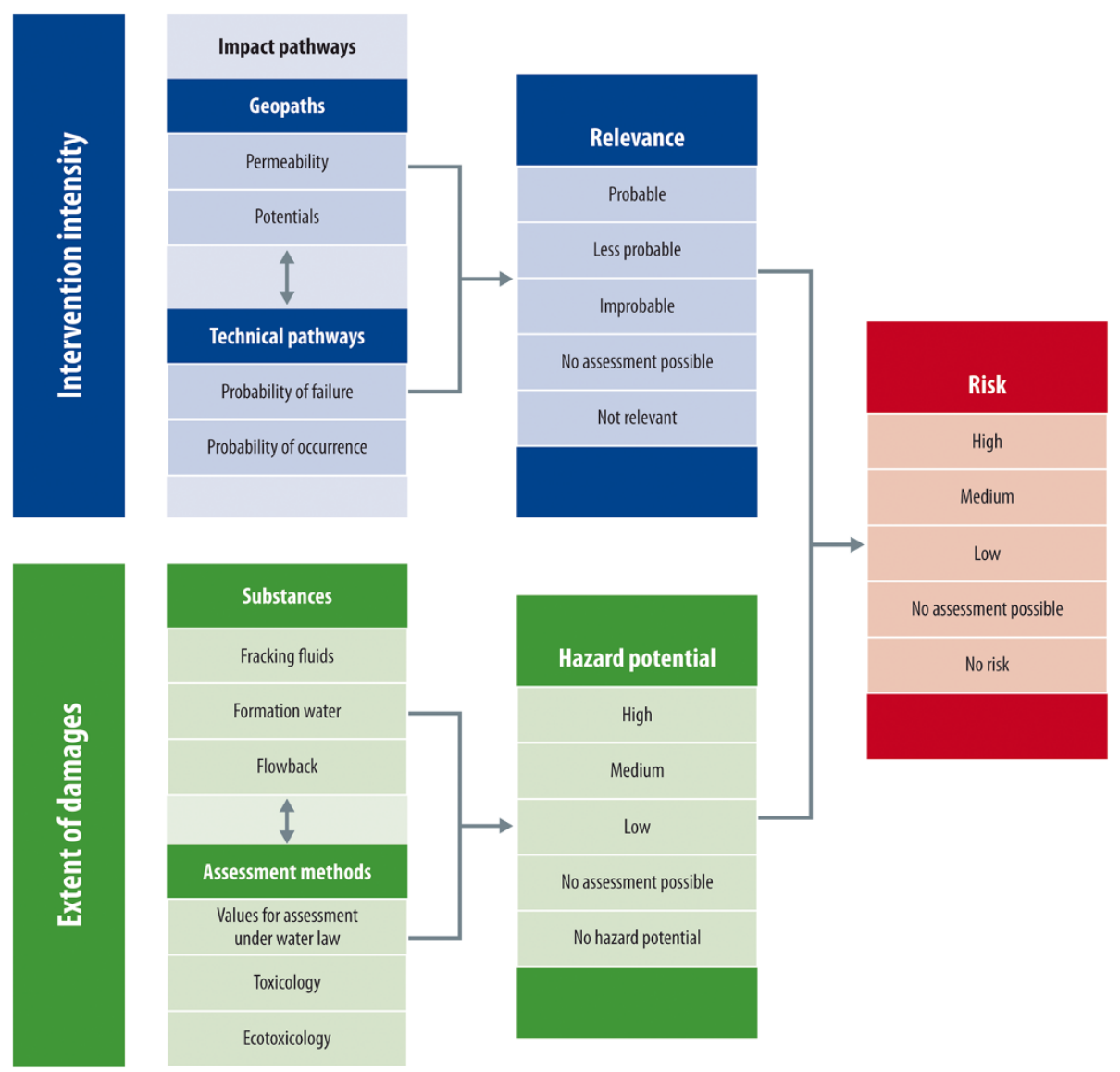

Figure 2 Structure of risk analysis for assessment of unconventional gas exploitation.

by multiplying the relevance of the impact pathway(s) and the hazard potential of the pertinent fluids (fracking fluids and formation water). Since the state of knowledge does currently not allow for numerical calculations, we propose a five-part scale to evaluate the relevance of impact pathways and the hazard potential of the fluids involved (Figure 2).

\section{Impact pathways}

Potential water-related impact pathways are shown schematically in Figure 3, considering both technical and geological impact pathways. In most cases, failures of technical systems need to occur (such as failures of the well casing) for activating potential geological impact pathways (such as migration along faults), except in the fracking horizon, where no technical barrier is in place. Technical impact pathways could be quantified by probabilities of occurrence or probabilities of failure if data suitable for the German geological, technical and legal conditions were available. For a geological impact pathway to be relevant for substance migration, both permeability and hydraulic potentials must be considered for each geosystem site-specifically. Without suitable numerical quantification, however, the relevance of geological impact pathways can be estimated only with great uncertainties, for example using worst-case approaches.

Pathway group 0 refers to (pollutant) discharges that occur directly at the ground surface, and especially in handling of fracking fluids (transport, storage, etc.) or flowback (e.g. via accidents or improper handling).

Pathway group 1 refers to potential (pollutant) discharges and migration along wells, i.e. to artificial underground pathways. With regard to the impact pathways involved, a distinction has to be made between production wells and old wells, such as wells from other explorations and uses.

Pathway group 2 comprises all impact pathways along geological faults. Significantly, the permeability along any given fault can vary, section-wise. Whereas deep-reaching, continuous faults can often be monitored, since the nearsurface locations of their outcrops are usually known, faults that affect only parts of the overburden are difficult to monitor.

Pathway group 3 comprises extensive rise, as well as lateral spreading, of gases and fluids through geological strata (for example, via an aquifer), without preferred pathways similar to those described for pathway groups 


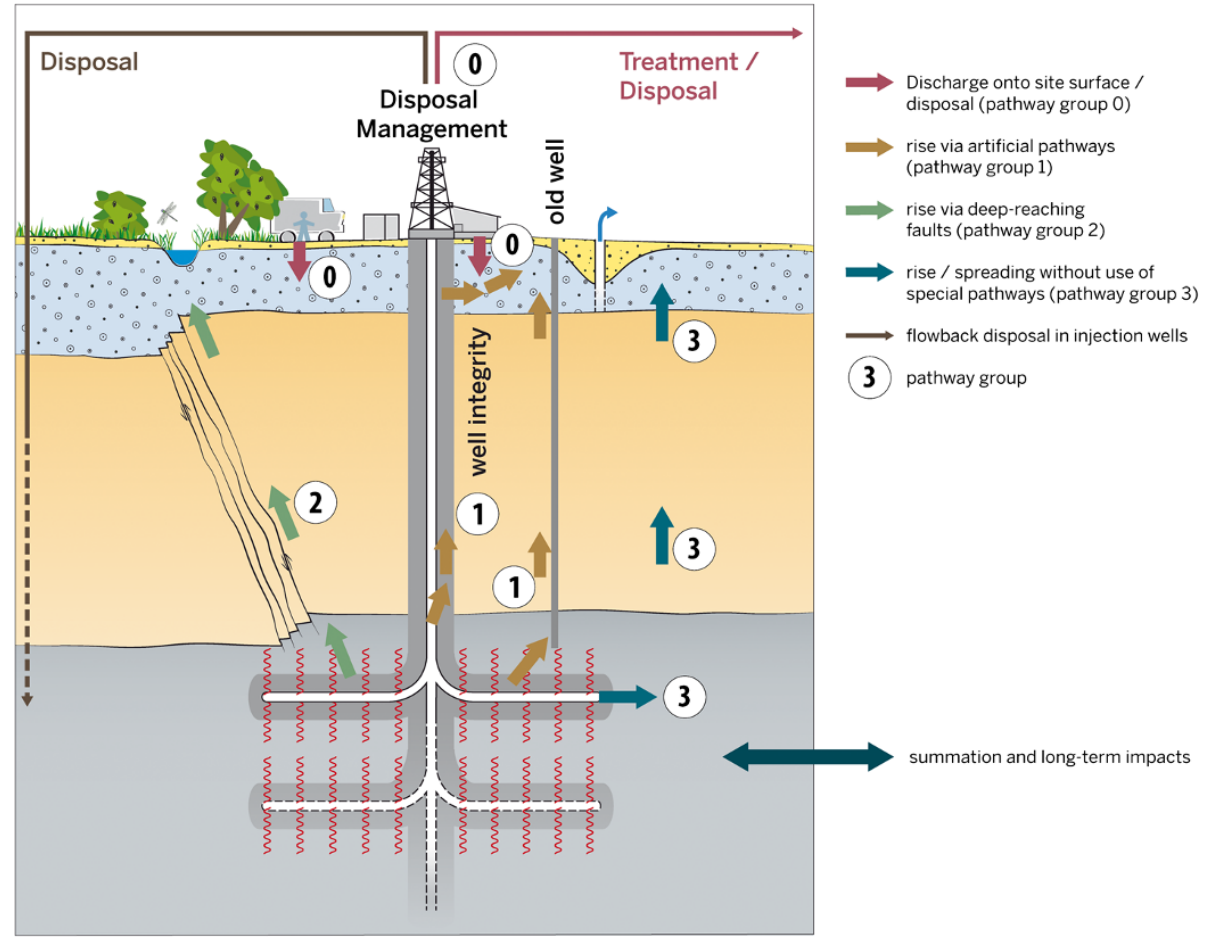

Figure 3 Schematics of potential impact pathways.

1 and 2. Impact pathways in pathway group 3 depend primarily on the prevailing geological and hydrogeological conditions.

Summation and combination effects of the aforementioned impact pathways must be taken into account appropriately. Since many flow processes in the deep underground take place slowly, the relevant long-term impacts need to be considered. Such estimation is possible only on the basis of an extensive understanding of the geological and hydrogeological conditions prevailing in deep underground horizons, although not enough data of the studied geosystems are currently available to support conceptual or even numerical models.

Furthermore, the flowback disposal needs to be assessed as additional impact pathway, especially if flowback disposal is via injection into underground disposal wells.

\section{Fracking fluids \\ Overview}

The fracking fluid is the hydraulic medium used for applying pressure to the rock strata inducing fracturing. With the fracking fluid, proppants (such as quartz sand) are transported into the created fractures in order to keep fractures from closing under the pressure of the surrounding rock and, thus, to ensure that the pathways created remain accessible for gas migration during the production phase. Fracking fluids usually contain a variety of chemical additives, with functions such as facilitating transport of proppants into fractures, preventing formation of precipitates, microbiological growth, formation of hydrogen sulphide, swelling of clay minerals, corrosion, and reducing fluid friction at high pump rates. Table 2 provides an overview of the functions of certain additives.

In the following we present information on the fracking fluids and additives that have so far been employed in Germany. We then presented a method for assessing the hazard potentials of the fracking fluids employed with regard to groundwater, especially with regard to human use of groundwater as drinking water, and as part of natural cycles. In applying the method we assess selected fracking fluids used in Germany to date and possible new improvements of such fluids.

\section{Fracking fluids used in Germany}

We relied primarily on publicly accessible data to obtain information on the fracking fluids used in unconventional reservoirs in Germany [23]; only in some cases information from non-publicly accessible sources were obtainable [24]. The information on the composition of the fracking fluids used is based mainly on analyses of safety data sheets of the commercial products used to prepare fracking fluids. It has been found that these safety data sheets are often the only available source of information on the identity and the concentrations of the additives used. For approval authorities, this situation creates considerable uncertainties and lack of knowledge 
Table 2 Functions of additives used in fracking fluids (based on $[4,9]$ )

\begin{tabular}{ll}
\hline Additive & Function \\
\hline Proppants & $\begin{array}{l}\text { Keeping the fractures created open under the pressure of the surrounding rock and } \\
\text { allows gas/fluid to flow to the well bore }\end{array}$ \\
$\begin{array}{l}\text { Scale inhibitors } \\
\text { Biocides }\end{array}$ & $\begin{array}{l}\text { Preventing deposits of poorly soluble precipitates, such as carbonates and sulphates } \\
\text { by sulphate-reducing bacteria }\end{array}$ \\
Iron control & $\begin{array}{l}\text { Preventing iron-oxide precipitation } \\
\text { Gelling agents }\end{array}$ \\
$\begin{array}{l}\text { Improving proppant transport } \\
\text { High-temperature stabilizer (temperature stabilizer) }\end{array}$ & $\begin{array}{l}\text { Preventing gel decomposition at high temperatures within the target horizon } \\
\text { Corrosion inhibitors }\end{array}$ \\
$\begin{array}{l}\text { Reducing the viscosity of gel-containing fracking fluids for depositing proppants } \\
\text { Solvents }\end{array}$ & $\begin{array}{l}\text { Protecting against equipment corrosion } \\
\text { Improving the solubility of additives }\end{array}$ \\
Crosslinkers & Controlling the pH of tracking fluids \\
Friction reducers & Increasing viscosity at higher temperatures, to improve proppant transport \\
Acids & Reducing friction within frac king fluids \\
Foams & $\begin{array}{l}\text { Pretreating perforated sections of the well, and cleaning them of cement and } \\
\text { drilling mud; dissolving acid-soluble minerals }\end{array}$ \\
H2S scavengers & Supporting proppant transport \\
Surfactants & Removing toxic hydrogen sulphide to protect equipment against corrosion \\
Clay stabilizers & Reducing surface tension of fluids \\
\hline
\end{tabular}

regarding the identity and the quantities of additives actually injected into the borehole.

Quantities used Information on fluid volumes was available for a total of 30 fracking fluids used in various unconventional reservoirs (and in one conventional reservoir) in Germany between 1982 and 2011. Most of the reservoirs in which the fluids were injected were tight gas reservoirs in Lower Saxony. The quantities used varied considerably, depending on the type of fracking fluid and the characteristics of the reservoirs. The quantities of fracking fluids used per frac ranged from less than $100 \mathrm{~m}^{3}$ to more than $4,000 \mathrm{~m}^{3}$. With the modern gel fluids used since 2000, an average of about $100 \mathrm{t}$ of proppants and about $7.3 \mathrm{t}$ of additives (of which usually less than $30 \mathrm{~kg}$ were biocides) were injected per frac. The quantities used can be quite large especially with multi-frac stimulations and/or use of slickwater fluids: for example, a total of about $12,000 \mathrm{~m}^{3}$ of water, $588 \mathrm{t}$ of proppants, and $20 \mathrm{t}$ of additives (of which $460 \mathrm{~kg}$ were biocides) were injected into the "Damme 3" borehole in three frac operations in 2008.

Commercial hydraulic fracturing products According to the available information, at least 88 different hydraulic fracturing products have been used to prepare fracking fluids in Germany. However, since data are available on only 21 fracking fluids (corresponding to about $21 \%$ of the approximate 300 fracs carried out in Germany), it must be assumed that other products have also been employed. For 80 of the 88 products, we were able to obtain manufacturers' or importers' safety data sheets that were either current or valid at the time the fracs were carried out. Evaluation of the available 80 safety data sheets revealed that:

- 6 products are classified as toxic,

- 6 are classified as dangerous to the environment,

- 25 are classified as harmful,

- 14 are classified as irritant,

- 12 are classified as corrosive, and

- 27 are classified as non-hazardous

according to directives $67 / 548 / \mathrm{EEC}$ or $1999 / 45 / \mathrm{EC}$, respectively. Several products are classified in more than one hazard class. With respect to the German water hazard classification (Wassergefährdungsklasse WGK), the commercial products were classified as follows according to the information in the safety data sheets:

- 3 preparations are classified as severely hazardous to waters,

- 12 preparations are classified as hazardous to waters,

- 22 preparations are classified as low hazardous to waters, 
- 10 preparations are classified as not hazardous for water.

A total of 33 of the safety data sheets available to the study authors provided no information on the water hazard class of the product.

Fracking additives Information on the fracking additives used in the hydraulic fracturing products was available to the study authors for 28 fracking fluids. Those fluids were used in about $25 \%$ of 300 fracs carried out in Germany. Evaluation of those 28 fracking fluids showed that, overall, at least 112 substances/substance mixtures have so far been used in Germany. For 76 of the 112 substances/substance mixtures, either unique Chemical Abstracts Service (CAS) numbers were provided or it proved possible to correct or determine the CAS number on the basis of a unique given substance name. A total of 36 substances/substance mixtures could not be uniquely identified, either because their composition was unknown or because the available safety data sheets referred only to unspecific chemical group names (such as aromatic ketones, inorganic salts, etc.).

\section{Hazard potentials of fracking fluids Comparison of two fracking fluids}

Since recipes for fracking fluids are normally tailored to specific reservoirs, the hazard potentials of each fluid need to be assessed site-specifically. Based on the assessment method described in the Methods section, we have assessed the two fluids used to date in shale gas and CBM reservoirs in Germany as two examples. Planned improvements of fracking fluids were taken into account by assessing two fluids mentioned by an operator as potentially being suitable for shale gas reservoirs and, possibly, CBM reservoirs (improvements of slickwater and gel fluids) [4].

The hazard potentials of the slickwater fluid employed in the shale gas reservoir in 2008 and a planned improved composition are compared in Table 3. The assessment concludes that the slickwater fluid used in 2008 has a high toxicological and ecotoxicological hazard potential. In the improved fracking fluid, three hazardous additives that were still being used in 2008 are replaced by substances with considerably lower hazard potentials. However, also the improved fluid seems to exhibit a high hazard potential, because of employing high concentrations of a formaldehyde-forming biocide, for which little data is available for assessing its behaviour, fate, toxicity, and formation of degradation products. The replacement of the three hazardous additives that were still being used in 2008 by substances with considerably lower hazard potentials must be critically evaluated, since the underlying database for assessing those additives has been available for years, suggesting that service companies, operators, and/or authorities in the past have not always adequately considered the possibilities of substituting hazardous additives.

Current developments aiming at reducing the numbers of additives used, at finding substitutes for substances that are highly toxic, carcinogenic, mutagenic, or toxic for reproduction, and at reducing or replacing biocidal agents, point to potential progress in the development of environmentally compatible fracking fluids. However, the authors can currently not evaluate the feasibility or progress of such efforts.

\section{Flowback}

\section{Quantities and composition}

After pressure has been applied to the gas-bearing formation, some of the injected fracking fluids are recovered

Table 3 Composition and hazard potential of two slickwater fluids

\begin{tabular}{|c|c|c|c|c|c|c|c|c|}
\hline \multirow[b]{2}{*}{ Function } & \multicolumn{4}{|c|}{ Fracking fluid used at Damme 3} & \multicolumn{4}{|c|}{ Planned improvement of a slickwater fluid } \\
\hline & Additive & $\begin{array}{c}\text { Dissolved } \\
\text { concentration } \\
\text { in fracking } \\
\text { fluid }\end{array}$ & $\begin{array}{c}\text { Risk quotient } \\
\text { based on } \\
\text { toxicological } \\
\text { assessment }\end{array}$ & $\begin{array}{c}\text { Risk quotient } \\
\text { based on eco- } \\
\text { toxicological } \\
\text { assessment }\end{array}$ & Additive & $\begin{array}{c}\text { Dissolved } \\
\text { concentration } \\
\text { in fracking } \\
\text { fluid }\end{array}$ & $\begin{array}{c}\text { Risk quotient } \\
\text { based on } \\
\text { toxicological } \\
\text { assessment }\end{array}$ & $\begin{array}{l}\text { Risk quotient } \\
\text { based on } \\
\text { eco-toxicological } \\
\text { assessment }\end{array}$ \\
\hline $\begin{array}{l}\text { Clay } \\
\text { stabilizer }\end{array}$ & $\begin{array}{l}\text { Tetramethyl- } \\
\text { ammonium } \\
\text { chloride }\end{array}$ & $520 \mathrm{mg} / \mathrm{L}$ & $1,733,000$ & $\begin{array}{c}\text { Database } \\
\text { insufficient } \\
(>2,600,000)\end{array}$ & $\begin{array}{l}\text { Cholinium } \\
\text { chloride }\end{array}$ & $750 \mathrm{mg} / \mathrm{L}$ & $<43$ & 210 \\
\hline $\begin{array}{l}\text { Friction } \\
\text { reducer }\end{array}$ & $\begin{array}{l}\text { Hydrotreated } \\
\text { light petroleum } \\
\text { distillates }\end{array}$ & $220 \mathrm{mg} / \mathrm{L}$ & 2,200 & 55,000 & Butyl diglycol & $350 \mathrm{mg} / \mathrm{L}$ & 40 & 6,600 \\
\hline Surfactant & $\begin{array}{l}\text { Ethoxylated } \\
\text { octylphenol }\end{array}$ & $36 \mathrm{mg} / \mathrm{L}$ & 120,000 & 20,000 & $\begin{array}{c}\text { Polyethylene } \\
\text { glycol monohexyl } \\
\text { ether }\end{array}$ & $130 \mathrm{mg} / \mathrm{L}$ & 743 & 760 \\
\hline Biozide & $\begin{array}{l}\text { Isothiazolinone } \\
\text { derivative }\end{array}$ & $4 \mathrm{mg} / \mathrm{L}$ & 7,520 & 72,000 & $\begin{array}{l}\text { (Ethylenedioxy)- } \\
\text { dimethanol }\end{array}$ & $1,000 \mathrm{mg} / \mathrm{L}$ & $10,000,000$ & $\begin{array}{c}\text { Database } \\
\text { insufficient } \\
(139,000)\end{array}$ \\
\hline
\end{tabular}

Assessment of the fracking fluid used 2008 for hydraulic fracturing in a shale gas reservoir at Damme 3 and of a planned improvement based on human- and ecotoxicologically derived risk quotients. 
along with formation water and gas extracted from the well. The so-called flowback consists of varying proportions of injected fracking fluids and co-extracted formation water. Initially, fracking fluids account for the larger share of flowback; later, formation water predominates. As a result of various hydrogeochemical processes that can occur within the reservoir horizon (Figure 4), flowback can contain other substances in addition to fracking additives and formation water constituents.

At the high pressures and temperatures prevailing in the target horizon, injected fracking additives may undergo chemical transformation and decomposition reactions in the presence of saline formation water. Microbiological decomposition reactions may occur as soon as the effects of the injected biocides diminish. In the process, metabolites can form that can pose toxicological and ecotoxicological risks potentially even exceeding the hazard posed by the parent substances that were injected.

Because the characteristics of formation water are always reservoir-specific, and because the proportions of extracted fracking additives vary, the characteristics of flowback have to be individually assessed for each site and pertinent time. Little information is available about the constituents of formation water in shale gas and CBM reservoirs in Germany, such as information about primary, secondary, and trace components, dissolved gases, organic substances, and NORM (Naturally Occurring Radioactive Material); regional and depth-oriented data is often missing.

At present, there is a lack of reliable analyses and mass balances that would allow for quantification of the variable mixing fractions, the fraction of the extracted fracking fluid, and possible reaction products. To date, no systematic measurements have been carried out for the purpose of identifying transformation and decomposition products in the flowback. Assessments of flowback from the "Damme 3" borehole carried out by Rosenwinkel et al. [25] concluded that only $8 \%$ of injected fracking fluids were being recovered as part of the flowback. Even though that percentage can be expected to increase as production continues, it seems certain that a substantial proportion of the fracking additives injected remains underground.

\section{Disposal of flowback}

Possible technical processes for treating flowback have been reviewed by Rosenwinkel et al. [25] concluding that none of those treatment options, at present, qualifies as "best available technology" within the meaning of the German Federal Water Act. In general, the following options are possibly suitable for disposing or recycling of flowback in Germany:

- Underground injection via disposal wells,

- treatment for discharge into surface water,

- treatment for discharge into the sewer system,

- recycle and reuse in future hydraulic fracturing operations.

Operators currently refer to underground disposal of flowback as an important prerequisite for (cost-effective) exploitation of unconventional gas reservoirs. From the perspective of the study authors, flowback disposal via deep-underground injection can entail risks requiring site-specific risk assessment and monitoring.

\section{Conclusions}

There is general lack of basic information that would be needed for any well-founded assessment of the pertinent

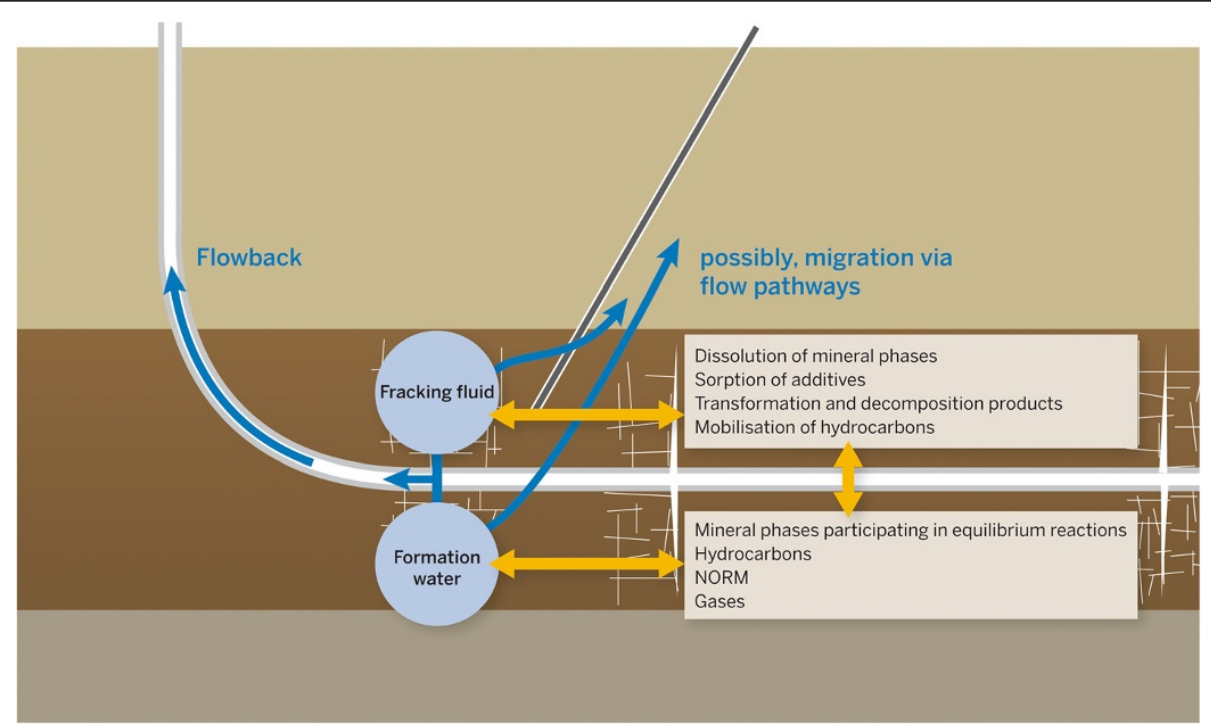

Figure 4 Hydrogeochemical processes affecting flowback formation via mixing of fracking fluids and formation water. 
risks and the degree to which they can be controlled by technical means. Examples of such missing data include information regarding the structures and properties of deep geological systems (permeabilities, potential differences), the identities of the fracking additives used, and the chemical and toxicological properties of such additives. There are several reasons for this lack of information and data: (a) the information and data are not (openly) accessible, (b) the information and data have not yet been evaluated, and/or (c) there are gaps in knowledge that can only be closed through additional studies and research.

By studying selected geological systems in which shale gas or CBM reservoirs in Germany are found or assumed [4] we concluded that site-specifically certain impact pathways could be relevant for fluid migration. Little reliable data are currently available that would provide a basis for the reliable exclusion of risks to near-surface water resources. Assessment of selected fracking fluids used in unconventional gas reservoirs in Germany, along with the available information on the characteristics of flowback, have revealed that injected fluids, and fluids requiring disposal, can pose considerable hazard potentials. In summary, the study concludes that currently missing knowledge and data prevent a profound assessment of the risks and their technical controllability in Germany.

\section{Recommendations}

In light of the shortcomings of the currently available data, and of the fact that environmental risks cannot be ruled out, we recommend from a standpoint of precautionary water resources management, that above-ground and below-ground activities for unconventional gas exploitation involving fracking should not be approved for exploration or exploitation in water protection areas (classes I through III), water-extraction areas for the public drinking water supply (even if not assigned as water protection areas), mineral spa protection zones, and near mineral water reserves. These areas should be excluded for such activities. This recommendation on denial of approval should be reviewed as more data become available. In areas known to have unfavourable geological and hydrogeological conditions (groundwater potentials and known impact pathways), no exploration and exploitation of unconventional gas (via deep-drilling and hydraulic fracturing) should be allowed.

Site-specific risk assessment should be carried out with regard to any future drilling with fracking, and to drilling and use of underground disposal wells for injection of flowback. Such analyses should take account of all relevant fluids, whether introduced or encountered (fracking additives, formation water and its reaction products, and flowback), and of the relevant geological and technical impact pathways. It is recommended that use of toxicologically and ecotoxicologically hazardous fluids, and flowback disposal in disposal wells - also in the tight gas reservoirs in Germany that have already been exploited for many years - be reassessed.

Since the potential risks of exploration and exploitation of unconventional gas projects can be reliably assessed only if reliable information on the relevant geological systems (and potential impact pathways) is available, we recommend that any exploration of gas reservoirs provides investigations of the larger regional geological and hydrogeological system.

We further recommended that additional data and experience not yet published or not yet assessed (e.g., cadaster of old wells, cadaster of disposal wells) are evaluated and results are published. We argue however that without new data it will not be possible to answer the question of whether, and where, economically exploitable unconventional gas reserves are present in Germany and which technology (with or without fracking) is suited for exploration. We thus support the idea of carrying out further exploration, including exploration involving deep drilling (but without fracking), and carrying out targeted research in the above-described framework, for the purpose of answering those questions.

We recommend that further actions are taken step-bystep. Clear criteria should be established for deciding whether or not the application of fracking should be allowed at a later time. Such criteria should cover both the hazard potential of fracking additives and the availability of reliable information about the geological and technical impact pathways involved. Clear criteria should be applied for approval of any further exploration and any later production. A catalogue of criteria for approval should be developed step-by-step, applying transparent approaches involving public participation.

We recommend that research and development are intensified in areas such as the long-term integrity of wells, techniques available for forecasting the widths and lengths of fractures generated by fracking, and the development of fracking fluids with lower hazard potential. Practical application of the relevant research findings should be monitored scientifically.

With regard to EIA obligations, we recommend that fracking projects be subject to general federal EIA obligations, and that such obligations include an "opening clause" to allow participation of the German federal states. The public participation required under EIA legislation should be expanded to include a project-monitoring component, since many findings regarding projects' potential environmental impacts cannot be obtained until the projects are actually underway. Careful review of requirements under water law should be assured, via clarification of pertinent requirements, and via a) introduction of an integrated project-approval procedure to be directed by an environmental authority subordinate to the Ministry for 
the Environment, or b) integration of mining authorities within the environmental administration.

The following two aspects are of central importance with regard to any continuation of exploration and exploitation of unconventional gas in Germany, regardless of the procedures applied: all work processes and results should be fully transparent, and all stakeholders should exercise trust in their dealings with each other. Efforts should include the establishment of a publicly accessible cadaster listing all fracking measures carried out in the past, along with the quantities and the compositions of the fluids used.

In the following sections, we propose special recommendations for further steps towards exploitation of unconventional gas reservoirs in Germany. The focus of the recommendations is on the next phase of pilot exploration, especially, exploration in geological systems for which no information, or very little information, is yet available concerning unconventional gas reservoirs they may contain. The objectives of the recommendations include:

- identifying hydrogeological problematic areas, and possible impact pathways, at an early stage, and proposing measures for ongoing monitoring,

- reducing the hazard potential of the fracking fluid potentially used.

\section{Special recommendations with regard to the area of geological systems and the aquatic environment}

The cause-and-effect relationships between deep-reaching and near-surface groundwater flow systems are of particular importance with regard to the water-related environmental impacts of unconventional gas exploitation projects. Such assessments require a detailed understanding of the hydrogeological systems involved, including:

- Conceptual hydrogeological models should be prepared that support reliable risk assessment for all potential impact pathways. The scope of such conceptual models should be large enough to support assessment of the impacts of exploration and exploitation of unconventional gas - via fracking - both for the specific sites and with regard to the large geological systems (system-oriented exploration).

- For areas in which water-related environmental impacts cannot be ruled out, numerical groundwater flow models should be prepared/refined in order to quantify the pertinent risks. This may involve preparing a regional model that can serve as a basis for local numerical models in the exploration area.

- The aforementioned numerical models have to be continually verified and calibrated on the basis of data and information obtained through monitoring (both prior and during the project). For monitoring to be effective, it must be based on an adequate understanding of the system involved. At the same time, the understanding of the system involved (conceptual or numerical model) can be improved by the monitoring data obtained. Monitoring-based project control requires meaningful indicators and an evaluation system. Ultimately, options must be available for stopping, limiting, or reversing any undesired developments. The models resulting from the aforementioned work steps provide an important basis for authorities' decisions regarding the approval of submitted projects, as well as possible ancillary provisions under water law.

- The necessary regional and local models must be provided by the mining company within the authorization procedure under mining law and water law, based on the requirements imposed by the competent mining and water authorities. A fracking project can be approved only when enough pertinent knowledge has been gained and adequate precaution has been taken to exclude any adverse impact on exploitable water resources.

\section{Special recommendations with regard to the area of substances}

Assessment of selected fracking fluids used in unconventional gas reservoirs in Germany, along with the available information on the characteristics of flowback, have revealed that injected fluids, and fluids requiring disposal, can pose considerable hazard potentials. In light of the gaps in knowledge, uncertainties and data deficits identified via research and assessment for the present study, the following recommendations for action are seen as important:

- Complete disclosure of all substances used, with regard to substance identities and quantities.

- Assessment of the toxicological and ecotoxicological hazard potentials of substances used, and provision of all physical-chemical and toxicological substance data required by the mining company. If relevant substance data are lacking, the gaps in the data must be eliminated - if necessary, via suitable laboratory tests or model calculations. In the process, the effects of relevant substance mixtures must be taken into account.

- Substitution of unsafe substances (especially, substances that are highly toxic, carcinogenic, mutagenic, or toxic for reproduction), reduction or substitution of biocides, reduction of the numbers of additives used, lowering of concentrations used. 
- Determination and assessment of the characteristics of site-specific formation water, with regard to constituents of relevance to drinking water quality (salts, heavy metals, Naturally Occurring Radioactive Material - NORM, hydrocarbons).

- Determination and assessment of the characteristics of site-specific flowback, with regard to constituents of relevance to drinking water quality (salts, heavy metals, NORM, hydrocarbons), and with regard to additives used (primary substances) and their transformation products (secondary substances); determination and assessment of the proportion of fracking fluids recovered with the flowback.

- Determination of the behaviour and fate of substances in the fracking horizon, via mass balancing of the additives used.

- Modelling of substance transport, for assessment of possible risks to any exploitable groundwater, from any migrating formation water and fracking fluids.

- Technical treatment and "environmentally sound" disposal of flowback, including description of all technically feasible treatment processes and of the possibilities for reusing substances. If injecting flowback into disposal wells, conducting of a site-specific risk analysis is recommended.

- Monitoring and system-oriented examination, including installation of near-surface groundwater observation wells to determine the reference condition with regard to additives and methane; if appropriate, installation of deep groundwater observation wells to determine the characteristics of formation water and the relevant hydraulic potentials.

\section{Methods}

Under German water law, the key requirement to be applied in assessing releases of substances into the groundwater is that releases must not adversely affect the water quality (Art. 48 (1) WHG, Federal Water Resources Management Act). An adverse effect on the quality of near-surface groundwater (i.e. of the exploitable groundwater that is integrated in natural cycles) has occurred, if water quality has worsened more than slightly.

An adverse effect on the water quality of groundwater must be assumed if relevant legal and sub-legal limit values, guide values, maximum values, and especially the "Geringfügigkeitsschwellenwerte" (de minimis thresholds, GFS) of the German Federal/State Working Group on Water (LAWA) [26] are exceeded in any exploitable groundwater. These de minimis thresholds are primarily based either on the maximum permitted concentration specified by the Ordinance on Drinking Water (Trinkwasserverordnung), or, if no maximum permitted concentration has yet been established, on toxicologically and ecotoxicologically derived threshold values. Thus, it is ensured that groundwater remains available as drinking water resource for human consumption, and it remains intact as a habitat and as part of natural cycles.

For the majority of the substances used as fracking additives, no de minimis thresholds or other water-lawbased assessment values have yet been established. Therefore, hygienic guidance values for drinking water (GVDW - maximum concentration of a substance in drinking water that can be tolerated for a lifetime without suffering adverse effects on health) or health orientation values (HOV - precautionary value for substances that cannot (or can only partially) be toxicologically assessed [27]) and ecotoxicologically established Predicted No Effect Concentrations (PNEC - maximum concentration of a substance at which no effects on organisms of an aquatic ecosystem are expected [28]) were assessed for such substances, or derived using published methods, following the concept of LAWA [26].

Relevant for the assessment is the concentration at the location where the substance enters exploitable groundwater resources. In case of substances entering groundwater from the surface (pathway group 0, e.g. accidents during transport and preparation of fracking fluids), the relevant substance concentration for the assessment is the concentration at the groundwater surface (see page water). By analogy, in the case of a possible release from the fracking horizon (and related migration via pathway groups 1 through 3 ), the concentration at the base of the exploitable groundwater aquifer should be used in the assessment.

The relevant substance concentrations can properly assessed only site-specifically. For potential migration and exposure scenarios, suitable models are needed that consider relevant hydraulic and geochemical transport, mixing, decomposition, and reaction processes along the underground flow pathway. No such models are available at present that have the necessary spatial resolution.

As long as suitable models are lacking, we propose to assess hazard potentials on the basis of substance concentrations in (undiluted) fracking fluids and formation water. Based on the current state of knowledge, we consider it not suitable to presume a considerable reduction of their hazard potential due to dilution along the underground flow pathways, because along the flow path dilution occurs mainly by mixing with saline groundwater, which can have considerable hazard potential of its own (see below); thus, mixing with such water would not necessarily reduce the hazard potential of fracking fluids. 
The pertinent hazard potentials of the fluids are assessed on the basis of the individual constituents, calculating substance-specific risk quotients of substance concentrations and assessment values (GFS, GVDW, HOV, or PNEC):

$$
\text { RiskQuotient }=\frac{\text { substance concentration in the fluid }}{\text { assessment value }}
$$

When a substance has a risk quotient $<1$, no hazard potential is expected, while a risk quotient $\geq 1$ represents potentially a toxicological or ecotoxicological hazard (hazard potential). In the present study, a risk quotient > 1,000 is assumed to represent a high hazard potential. This value is given as an example and has not been scientifically established; it needs to be site-specifically reviewed on the basis of exposure scenarios - using numerical models for example.

\section{Competing interests}

The authors declare that they have no competing interests.

\section{Authors' contributions}

The authors contributed in equal parts to this publication. All authors read and approved the final manuscript.

\section{Acknowledgements}

The authors would like to thank the German Federal Environment Agency (UBA) for financing the study and the project partners [Gassner, Groth, Siederer \& Coll.] and TU Darmstadt (Prof. Dr. Sass) for their collaboration.

\section{Author details}

'IWW Water Centre, Department Water Resources Management, Moritzstrasse 26, Muelheim 45476, Germany. ${ }^{2}$ ahu AG Wasser Boden Geomatik, Kirberichshofer Weg 6, Aachen 52066, Germany.

Received: 6 January 2014 Accepted: 9 April 2014

Published: 15 May 2014

\section{References}

1. Bundesanstalt für Geowissenschaften und Rohstoffe: Abschätzung des Erdgaspotenzials aus dichten Tongesteinen (Schiefergas) in Deutschland. Hannover: 2012. http://www.bgr.bund.de/DE/Themen/Energie/Downloads/ BGR_Schiefergaspotenzial_in_Deutschland_2012.pdf?_blob= publicationFile\&v=7.

2. Sachverständigenrat für Umweltfragen: Fracking zur Schiefergasgewinnung: Ein Beitrag zur energie- und umweltpolitischen Bewertung. Aktuelle Stellungnahme Nr. 18. Berlin: 2013. http://www.umweltrat.de/SharedDocs/ Downloads/DE/04_Stellungnahmen/2012_2016/2013_05_AS_18_Fracking. pdf?_blob=publicationFile.

3. Bundesanstalt für Geowissenschaften und Rohstoffe: Energiestudie 2013. Reserven, Ressourcen und Verfügbarkeit von Energierohstoffen. Hannover: 2013:112. http://www.bgr.bund.de/DE/Themen/Energie/Downloads/ Energiestudie_2013.pdf?_blob=publicationFile\&v=5.

4. Umweltbundesamt: Umweltauswirkungen von Fracking bei der Aufsuchung und Gewinnung von Erdgas aus unkonventionellen Lagerstätten - Risikobewertung, Handlungsempfehlungen und Evaluierung bestehender rechtlicher Regelungen und Verwaltungsstrukturen. -Gutachten im Auftrag des Umweltbundesamtes. Berlin; 2012. http://www.umweltbundesamt.de/uba-info-medien/4346.html.

5. Ministerium für Klimaschutz, Umwelt, Landwirtschaft, Natur- und Verbraucherschutz des Landes NRW: Gutachten mit Risikostudie zur Exploration von Erdgas aus unkonventionellen Lagerstätten in Nordrhein-Westfalen und deren Auswirkungen auf den Naturhaushalt, insbesondere die öffentliche Trinkwassergewinnung. Düsseldorf; 2012. http://www.umwelt.nrw.de/umwelt/wasser/trinkwasser/erdgas_fracking.

6. IWW Rheinisch-Westfälisches Institut für Wasser Beratungs- und Entwicklungsgesellschaft mbH: Wasserwirtschaftliche Risiken bei Aufsuchung und Gewinnung von Erdgas aus unkonventionellen Lagerstätten im Einzugsgebiet der Ruhr. Gutachten des IMW im Auftrag der Arbeitsgemeinschaft der Wasserwerke an der Ruhr e.V. und des Ruhrverbandes. Mülheim; 2013. http://www. awwr.de/fileadmin/download/download_2013/studie_fracking_einzugsgebiet_ruhr.pdf, http://www.ruhrverband.de/wissen/forschung-entwicklung/ fracking/.

7. U.S. Environmental Protection Agency: Evaluation of impacts to underground sources of drinking water by hydraulic fracturing of coalbed methane reservoirs. 2004. http://water.epa.gov/type/groundwater/ uic/class2/hydraulicfracturing/wells_coalbedmethanestudy.cfm.

8. U.S. Environmental Protection Agency: Plan to Study the Potential Impacts of Hydraulic Fracturing on Drinking Water Resources. Washington; 2011. http://water.epa.gov/type/groundwater/uic/class2/hydraulicfracturing/ upload/hf_study_plan_110211_final_508.pdf.

9. Tyndall Centre: Shale gas: a provisional assessment of climate change and environmental impacts. Manchester; 2011. http://www.tyndall.ac.uk/ shalegasreport.

10. Waxman HA, Markey EJ, Degette D: Chemicals used in hydraulic fracturing. In U.S. House of Representatives Committee on Energy and Commerce Minority Staff. Washington; 2011. http://democrats. energycommerce.house.gov/sites/default/files/documents/HydraulicFracturing-Chemicals-2011-4-18.pdf.

11. New York State Department of Environmental Conservation: Revised Draft Supplemental Generic Environmental Impact Statement. Chapter 5: Natural gas development activities \& high-volume hydraulic fracturing. New York; 2011. http://www.dec.ny.gov/docs/materials_minerals_pdf/ rdsgeisch50911.pdf.

12. Ewen C, Borchardt D, Richter S, Hammerbacher R: Risikostudie Fracking Übersichtsfassung der Studie "Sicherheit und Umweltverträglichkeit der Fracking-Technologie für die Erdgasgewinnung aus unkonventionellen Quellen" erstellt im Zusammenhang mit dem InfoDialog Fracking. Darmstadt; 2012. http://dialog-erdgasundfrac.de/sites/dialog-erdgasundfrac. de/files/Ex_risikostudiefracking_120518_webprint.pdf.

13. Hessischer Landtag: 60. Sitzung des Ausschusses für Umwelt, Energie, Landwirtschaft und Verbraucherschutz. Wiesbaden; 2013. http://www. hessischer-landtag.de/icc/med/bb7/bb700690-9433-e31a-628b31402184e373,11111111-1111-1111-1111-111111111111.pdf.

14. Landesamt für Bergbau, Energie und Geologie Niedersachsen: Mindestanforderungen an Betriebspläne, Prüfkriterien und Genehmigungsablauf für hydraulische Bohrlochbehandlungen in Erdöl- und Erdgaslagerstätten in Niedersachsen. Clausthal-Zellerfeld. Rundverfügung vom 31.10.2012. http://www.lbeg.niedersachsen.de/download/72198/Mindestanforderungen_an_Betriebsplaene_Pruefkriterien_und_ Genehmigungsablauf_fuer_hydraulische_Bohrlochbehandlungen_in_ Erdoel__und_Erdgaslagerstaetten_in_Niedersachsen.pdf.

15. Hammerbacher Beratung \& Projekte: Statusbericht von ExxonMobil zur Umsetzung der Risikostudie Fracking. Osnabrück. Protokoll vom 6. November 2012, Osnabrück http://www.erdgassuche-in-deutschland.de/ dialog/info_dialog_fracking_status.html.

16. Ministerium für Klimaschutz, Umwelt, Landwirtschaft, Natur- und Verbraucherschutz des Landes Nordrhein-Westfalen, Ministerium für Klimaschutz, Umwelt, Landwirtschaft, Natur- und Verbraucherschutz des Landes Nordrhein-Westfalen: Pressemitteilung vom 07.09.2012 Umweltministerium und Wirtschaftsministerium legen Risikogutachten zu Fracking vor. http://www.umwelt.nrw.de/ministerium/service_kontakt/archiv/ presse2012/presse120907_a.php.

17. Remmel J: Erdgas aus unkonventionellen Lagerstätten. gwf Wasser Abwasser 2012, 11:1121.

18. Niedersächsisches Ministerium für Wirtschaft, Arbeit und Verkehr: Gemeinsame Presseinformation von Minister Wenzel und Lies vom 17.03.2014 - Ja zur Erdgasförderung! Nein zu umwelttoxischen Substanzen unter Tage! http://www.mw.niedersachsen.de/portal/live.php? navigation_id=5459\&article_id $=123032 \& \_p s m a n d=18$.

19. Bundesministerium für Umwelt, Naturschutz und Reaktorsicherheit: Vorschlag zur Änderung von UVP-V und Wasserhaushaltsgesetz. http://www.bmu.de/themen/wasser-abfall-boden/binnengewaesser/ gesetzesaenderung-zu-fracking.

20. Deutscher Verein des Gas- und Wasserfaches e.V: Stellungnahme vom 21. März 2013 zum Entwurf eines Gesetzes zur Änderung des Wasserhaushaltsgesetzes vom 7. März 2013 und Entwurf einer Verordnung zur Änderung der Verordnung über die 
Umweltverträglichkeitsprüfung bergbaulicher Vorhaben vom 11. März 2013 in Bezug auf die Umweltverträglichkeitsprüfung bei Bohrungen mit Einsatz der Fracking-Technologie. http://www.dvgw.de/wasser/ressourcenmanagement/gewaesserschutz/fracking/.

21. BGR, GFZ \& UFZ: Abschlusserklärung zur Konferenz "Umweltverträgliches Fracking?". Hannover; 2013. am 24./25. Juni 2013 (Hannover-Erklärung). http://www.bgr.bund.de/DE/Gemeinsames/Nachrichten/Neranstaltungen/ 2013/GZH-Veranst/Fracking/Downloads/Hannover-Erklaerung-Finalfassung.pdf.

22. Gelsenwasser AG, Arbeitsgemeinschaft der Wasserwerke an der Ruhr e.V. Deutscher Brauer-Bund e.V., Verband Deutscher Mineralbrunnen e.V. \& Wirtschaftsvereinigung Alkoholfreie Getränke e.V: Gelsenkirchener Erklärung: Wasserversorger, Bierbrauer, Mineral- und Heilbrunnenbetriebe sowie Erfrischungsgetränkehersteller fordern Schutz vor Fracking. Gelsenkirchen: 2013. (24.10.2013) http://www. gelsenwasser.de/fileadmin/download/unternehmen/presse/ gelsenkirchener_erklaerung.pdf.

23. ExxonMobil Central Europe Holding GmbH: Frack-Flüssigkeiten; http://www.erdgassuche-in-deutschland.de/erkundung_foerderung/ frac_fluessigkeiten/index.html.

24. Bezirksregierung Arnsberg: Gewinnung von Erdgas aus unkonventionellen Lagerstätten - Erkundungsmaßnahmen der CONOCO Mineralöl GmbH in den Jahren 1994 - 1997. Arnsberg; 2011. 61.01.25-2010-9.

25. Rosenwinkel KH, Weichgrebe D, Olsson O: Gutachten Stand der Technik und fortschrittliche Ansätze in der Entsorgung des Flowback des Instituts für Siedlungswasserwirtschaft und Abfall (ISAH) der LeibnizUniversität Hannover zum Informations- und Dialogprozess über die Sicherheit und Umweltverträglichkeit der Fracking-Technologie für die Erdgasgewinnung. Hannover: 2012. http://dialog-erdgasundfrac.de/sites/ dialog-erdgasundfrac.de/files/Gutachten\%20zur\%20Abwasserentsorgung\% 20und\%20Stoffstrombilanz\%20ISAH\%20Mai\%202012.pdf.

26. LAWA - Bund/Länder-Arbeitsgemeinschaft Wasser: Ableitung von Geringfügigkeitsschwellen für das Grundwasser. Düsseldorf: 2004. http://www.lawa.de/documents/GFS-Bericht-DE_a8c.pdf.

27. Umweltbundesamt: Bewertung der Anwesenheit teil- oder nicht bewertbarer Stoffe im Trinkwasser aus gesundheitlicher Sicht. Empfehlung des Umweltbundesamtes nach Anhörung der Trinkwasserkommission des Bundesministeriums für Gesundheit. Bundesgesundheitsbl Gesundheitsforsch Gesundheitsschutz 2003, 46:249-251.

28. European Commission: Technical Guidance Document in support of Commission Directive 93/67/EEC on Risk Assessment for new notified substances, Commission Regulation (EC) No 1488/94 on Risk Assessment for existing substances and Directive 98/9/EC of the European Parliament and of the Council concerning the placing of biocidal products on the market, Part II. Ispra; 2003. http://ihcp.jrc.ec.europa.eu/ our_activities/public-health/risk_assessment_of_Biocides/doc/tgd.

doi:10.1186/2190-4715-26-10

Cite this article as: Bergmann et al:: Potential water-related

environmental risks of hydraulic fracturing employed in exploration and exploitation of unconventional natural gas reservoirs in Germany.

Environmental Sciences Europe 2014 26:10.

\section{Submit your manuscript to a SpringerOpen ${ }^{\circ}$ journal and benefit from:}

- Convenient online submission

- Rigorous peer review

- Immediate publication on acceptance

- Open access: articles freely available online

- High visibility within the field

- Retaining the copyright to your article

Submit your next manuscript at $\gg$ springeropen.com 